\title{
Cities Gone Wild
}

\section{Tyson E. Lewis ${ }^{1}$}

Published online: 20 April 2020

(C) Springer Nature Switzerland AG 2020

Keywords Rewilding · Henri Lefebvre · Dystopian films · Critical animal studies · Exopedagogy $\cdot$ City $\cdot$ Critical ecological studies

In the popular dystopian imagination, post-apocalyptic cities are often depicted as empty of people. Think of the sci-fi classic The Omega Man (Sagal 1971), a lone white guy wandering around a major metropolitan city center encountering no one, only discarded objects and the unbearable silence of a world that has died, or, for a more updated version, there's 28 Days Later (Boyle 2002) and the early, harrowing scene when Jim (Cillian Murphy) awakes from a surgery only to discover that everyone has disappeared. Such movies evoke fear of mass disappearance.

The catastrophe feared is one of absence. Whereas many dystopian films evoke shock through spectacular destruction on a grand scale (earthquakes ripping buildings apart, tsunamis flooding whole neighborhoods, fires engulfing vast territories), mass disappearance is anti-spectacular. It is a quiet kind of terror that whispers equally to world collapse, but in this case, through the visual language of the void rather than through the thrills of surplus and excess.

In the midst of the coronavirus pandemic, images of mass disappearance have now become a reality. On the Internet and on social media platforms, one finds thousands of pictures of deserted streets, empty buildings, and so forth. Instead of iconic buildings being blown up or destroyed, we see them silent and alone - monuments to a hidden civilization that is under threat of erasure. It would seem that real dystopian nightmares come silently.

Yet the absence of human inhabitants is not an absolute absence. Indeed, such a reading reasserts the centrality of the human and its presence as the constitutive feature of worldhood and, in this sense, merely recapitulates old forms of anthropocentrism. The ideology of absence mistakes the lack of human actors for lack as such. For this reason, I find images such as the post-apocalyptic world encountered in the opening sequence in the film 12 Monkeys (Gilliam 1995) more interesting and compelling than

Tyson E. Lewis

Tyson.Lewis@unt.edu

1 University of North Texas, Denton, TX, USA 
the aforementioned films. The protagonist, James Cole (Bruce Willis), ventures to the surface of the devastated, burned out Earth. Certainly, there is an absence of human signs of life, but living in the rubble and the ruins of a crumbling city are a host of animals, including a massive grizzly bear. The world has been repopulated by a variety of living things, big and small, that now inhabit the spaces and places once built to accommodate human-oriented actions and purposes. Thus, mass disappearance of humans creates the condition for a mass migration of animals into otherwise restricted zones, producing zoomorphic heterotopias in a post-Anthropocene world.

As of this writing, we are already seeing figurations of the occupation of cities by all sorts of creatures in images of cities infected by coronavirus. Wild Orme Kashmiri goats have been photographed wandering through the streets of downtown of Llandudno, Wales. They were spotted eating hedges and climbing building walls. Under regulations prohibiting leaving homes except to buy groceries, pick up medicine from pharmacies, or engage in essential tasks, residents of San Francisco have witnessed an uptick in coyote sightings. Without cars to deter them, these resourceful animals have started exploring new territories once too dangerous to enter during daylight hours (Garcia 2020). Agence France-Presse (2020) has reported a sika deer roaming through metro stations of Nara, Japan, while a wild boar infiltrates Barcelona. Gangs of wild turkeys strut through Oakland, California, while a puma slinks through the center of Santiago, Chile.

What is shocking to us humans is the speed with which non-human animals have reclaimed the habitats that were originally taken from them. In a matter of weeks (not months or years), non-human animals have decided to breach the barricades humans constructed around their built environments, demonstrating how fragile such barricades are to begin with. Topological redistribution of spatial configurations signals a posthuman politics of occupation.

Indeed, zoomorphic geographic experimentation could quickly speedball into the non-human animal equivalent of Occupy Wall Street. In both cases, what is at stake is the suspension of the capitalist functionality of space. But the potential for wild occupations unleashed by the biopolitical management of coronavirus is perhaps more radical, cutting to the very root of the anthropological machinery that underlies capitalism in the first place. Cities are going feral, while humans sit inside their fragile domiciles watching through binoculars (or obsessively wedded to their computer screens). But this is a shame, as coronavirus has created an opening through which social distancing might be replaced with new forms of environmental intimacy with non-human others.

Of course cities are already homes for millions of human and non-human creatures. But most of these non-human co-dwellers live subaltern lives, in shadows and sewers, only venturing out under the protective cloak of darkness. The rewilding process brought about by social distancing brings to the surface the permeability of spatial separations along species lines. Infrastructure is played with by hooves rather than hands. And these visitors demand a new notion of citizenship, one which is not exclusive but inclusive. If Henri Lefebvre (1996) once argued for an expansion of who has a right to the city, perhaps we are now in a position to pose this question to non-human animal co-dwellers who have occupied the streets.

Perhaps coronavirus is opening up a new phase of city development. For Lefebvre, cities have grown through three historical phases. First, industrialization tore down 
existing, traditional urban spaces and reconstructed them to fit the needs and interests of capitalist manufacturing. This is the city as a planned, optimized space of production. The second phase saw the expansion of the urban outward into rural settings, creating suburban zones in the service of industry. Lefebvre refers to the third phase as deurbanized urbanization of city centers. Here, cities empty out to make space for office buildings and large, real-estate developments by white-collar elites. But coronavirus teaches us that we can now add another phase: de-urbanized rewilding of the city. In this phase, humans are displaced by an abundance of non-human animal co-dwellers who suddenly enter the streets and demand their own right to the city. Those at the forefront of this new reality would be human laborers who remain out in the streets maintaining infrastructure, delivering packages, and so forth. Such labor is physically connected to specific conditions in ways that white-collar labor-capable of being mobile, virtual, and thus disembodied - is not. In this sense, blue-collar workers have an opportunity for becoming a new green-collar vanguard for environmental intimacy that white elites remain (safely) sheltered from.

In the first three phases of Lefebvre's historical sketch, the positive and progressive tendencies of cities have been systematically under attack by industrialization, which reifies and instrumentalizes them. The positive tendencies of cities, according to Lefebvre, include encountering, simultaneity, and centralization. The right to the city is a right to encounters that are open-ended and dynamic and that are horizontal and expressive. These encounters can be juxtaposed next to exchange and extraction as the dual logics of the capitalist co-optation of cities for production purposes. The right to the city is a right to reclaim centrality, meaning that the center opens up to the margins and the excluded and the oppressed can thus return to the heart of the city and partake in decision-making. And the right to the city is a right to partake in equal measure in the simultaneity of encounters, forming mobile hubs of activity in, across, below, and above the surfaces of the city. In sum, these three dimensions concern the right to play with the city by putting its progressive forces into play, making the city into an emergent performance.

The emergent performances in our current city centers offer up strange new, zoomorphic polyrhythms. Lefebvre argues against the unirhythmic monotony of the industrial, capitalist city and, instead, calls on us to fight to preserve polyrhythmic diversity as it emerges from a multitude of swarming encounters. The more diverse the soundtrack of a city, the healthier the city is. Polyrhythmic profiles are compositions of multiple overlapping and potentially conflicting rhythmic patterns. Lefebvre highlights four different rhythmic pairs, including cosmic and mechanic, state and city, daily and extra-daily, and private and public rhythms. For the pandemic city, the cosmic rhythms that are normally in the background, buried behind the pulsations of public, state, daily, and mechanical rhythms, surge to the foreground. The result is a new soundscape that is not immediately subservient to capitalist rhythms of production and distribution. Again, one should not hear the absence of cars as a mere deficit or index of a lack, but rather as an opportunity for posthuman, zoomorphic rhythm analysis.

In the zoomorphic heterotopia we see emerging in pandemic cities, non-human animals are demanding a right to the city by occupying its infrastructure. They are opening up the possibility for expanded understandings of city encounters that cross species distinctions. Through their interests, needs, and desires, they are reconfiguring where, when, and how city centers might appear. And they are creatively proposing a 
new composition of simultaneous actions (for instance, foraging and shopping, trash collecting and scavenging, pipelaying and burrow digging). The result is a wild new polyrhythmic soundscape defining the urban environment. Indeed, such experimentation challenges even Lefebvre's notion of polyrhythmic diversity, as it highlights how cities have been overtly dominated by the unirhythms of human actions.

To view (and hear!) the emergent zoomorphic heterotopia not as a warning but as a promise is to embrace the exopedagogical lesson of the pandemic city (Lewis and Kahn, 2010). Exopedagogy is a pedagogy of exodus from anthropocentric ways of thinking and being. The posthuman occupation of cityscapes around the world offers a pedagogy in topological experimentation. Suddenly the city becomes an extended ecotone, or zone of transition between two separate biomes (for instance, forest and city). It is where two communities (human and non-human) meet and negotiate/ integrate. Perhaps we can suggest that Lefebvre's clarion call can be adjusted. We no longer need a right to the city so much as a right to the city as a heterotopic ecotone defined by encounters that promote and sustain environmental intimacies between human and non-human citizens.

Below the biopolitical management of human populations in cities there exists a biopower of occupation that subverts attempts to reestablish immunized, speciesdetermined territorial boundaries. This biopower is immanently productive, introducing the possibility of zoomorphic rewilding as a new ethico-political foundation for a posthuman right to the city. To return to business as usual in a post-pandemic world would be to miss this opportunity to join with non-human animal city dwellers in a moment of environmental intimacy.

\section{References}

Agence France-Presse. (2020). Coronavirus: wild animals take back world's empty city streets as people stay indoors. South China Morning Post, 30 March. https://www.scmp.com/news/world/article/3077518 /coronavirus-wild-animals-take-back-worlds-empty-city-streets-people-stay. Accessed 3 April 2020.

Boyle, D. (2002). 28 Days Later [motion picture]. London: DNA Films and UK Film Council.

Garcia, S. E. (2020). When humans are sheltered in place, wild animals will play. The New York Times, 1 April. https://www.nytimes.com/2020/04/01/science/coronavirus-animals-wildlife-goats.html. Accessed 3 April 2020.

Gilliam, T. (1995). 12 Monkeys [motion picture]. Los Angeles: Atlas Entertainment and Classico.

Lefebvre, H. (1996). Writings on the cities. London: Wiley-Blackwell.

Lewis, T. E., \& Kahn, R. (2010). Education out of bounds: reimagining cultural studies for a posthuman age. New York: Palgrave Macmillan.

Sagal, B. (1971). The Omega Man [motion picture]. Los Angeles: Walter Seltzer Productions. 